\title{
Persistence of Transported Lichen at a Hummingbird Nest Site
}

Graves, Gary R.; Forno, Manuela Dal

Published in:

Northeastern Naturalist

DOI:

$10.1656 / 045.025 .0410$

Publication date:

2018

Document version

Publisher's PDF, also known as Version of record

Document license:

CC BY-NC

Citation for published version (APA):

Graves, G. R., \& Forno, M. D. (2018). Persistence of Transported Lichen at a Hummingbird Nest Site.

Northeastern Naturalist, 25(4), 656-661. https://doi.org/10.1656/045.025.0410 


\title{
BioOne COMPLETE
}

\section{Persistence of Transported Lichen at a Hummingbird Nest Site}

\author{
Authors: Gary R. Graves, and Manuela Dal Forno \\ Source: Northeastern Naturalist, 25(4) : 656-661 \\ Published By: Eagle Hill Institute \\ URL: https://doi.org/10.1656/045.025.0410
}

BioOne Complete (complete.BioOne.org) is a full-text database of 200 subscribed and open-access titles in the biological, ecological, and environmental sciences published by nonprofit societies, associations, museums, institutions, and presses.

Your use of this PDF, the BioOne Complete website, and all posted and associated content indicates your acceptance of BioOne's Terms of Use, available at www.bioone.org/terms-of-use.

Usage of BioOne Complete content is strictly limited to personal, educational, and non-commercial use. Commercial inquiries or rights and permissions requests should be directed to the individual publisher as copyright holder.

BioOne sees sustainable scholarly publishing as an inherently collaborative enterprise connecting authors, nonprofit publishers, academic institutions, research libraries, and research funders in the common goal of maximizing access to critical research. 


\title{
Persistence of Transported Lichen at a Hummingbird Nest Site
}

\author{
Gary R. Graves ${ }^{1,2, *}$ and Manuela Dal Forno ${ }^{3}$
}

\begin{abstract}
Archilochus colubris (Ruby-throated Hummingbird) invariably decorate the exterior surface of their nests with living foliose lichen. Lichen fragments may be carried considerable distances, but it is unknown whether transported thalli survive at nest sites. Here we report the multi-year persistence of a transported thallus of Myelochroa aurulenta (Powdery Axil-bristle Lichen) at a hummingbird nest site. Our observation suggests that hummingbirds may be important dispersal agents for foliose lichens.
\end{abstract}

\section{Introduction}

Avian transport of lichen is amply documented by a voluminous literature on nest building (Bent 1940; Hansell 1996, 2000; Richardson 1974; Richardson and Young 1977), but the extent to which birds may be biologically important dispersal agents of lichens has been sparingly addressed (Bailey and James 1979, Lewis et al. 2014). Many species of hummingbirds adorn the surface of their nests with foliose lichens (Bent 1940, Schuchmann 1999). Lichen-ornamented nests are thought to mimic knots or swellings on tree branches (Collias and Collias 1984, Hansell 1996). Palecolored lichen could also confer crypsis by making the nests appear to blend into the background. Lichen use appears invariant in Archilochus colubris (L.) (Rubythroated Hummingbird), the only breeding hummingbird in eastern North America (Audubon 1835, Wilson 1828). Every detailed nest description published during the past 2 centuries has mentioned lichen ornamentation, e.g.:

"The outward coat is formed of small pieces of a species of bluish grey lichen that vegetates on old trees and fences, thickly glued on with the saliva of the bird, giving firmness and consistency to the whole, as well as keeping out moisture ... The base of the nest is continued round the stem of the branch, to which it closely adheres; and, when viewed from below, appears a mere mossy knot or accidental protuberance." (Wilson 1828)

Although it is now recognized that lichen, bud scales, flower pappi, and other plant materials are bound with spider silk rather than saliva (Saunders 1929, Tyler 1940), Wilson's description was otherwise accurate. Several species of foliose lichens of eastern North America have pale greenish-gray or gray thalli with brown

\footnotetext{
${ }^{1}$ Department of Vertebrate Zoology, National Museum of Natural History, Smithsonian Institution, Washington, DC 20013. ${ }^{2}$ Center for Macroecology, Evolution, and Climate, Natural History Museum of Denmark, University of Copenhagen, Copenhagen, Denmark. ${ }^{3}$ Department of Botany, National Museum of Natural History, Smithsonian Institution, Washington, DC 20013. *Corresponding author - gravesg@si.edu.
}

Manuscript Editor: David Richardson 
or black ventral (lower) surfaces (Brodo et al. 2001). Female hummingbirds prise lichen fragments from bark or wood substrates, carry them to nest sites, and carefully arrange them on the exterior surfaces of the nest with the pale (upper) surfaces of the thalli facing outward. This arrangement places rhizines, the root-like attachment structures on the ventral surfaces of lichen thalli, in direct contact with the nest matrix and bark of the supporting branch. To date, only a single peer-reviewed paper has addressed the taxonomic identity of lichens used as hummingbird nest material (McCormac and Showman 2009-2010). Those authors identified 5 species of foliose lichen in a collection of 11 Ruby-throated Hummingbird nests collected in Ohio: Parmelia sulcata Taylor, Punctelia sp., Flavoparmelia caperata (L.) Hale, Parmotrema sp., and Myelochroa aurulenta (Tuck.) Elix \& Hale.

Most breeding populations of Ruby-throated Hummingbirds are believed to be double-brooded, building 2 nests each breeding season, although nests may occasionally be used twice (Tyler 1940, Weidensaul et al. 2013). Nests usually fall apart or are blown down between breeding seasons. Until our study, it was unknown whether residual lichen fragments remain attached to the nest substrate, reestablish rhizine attachments, or grow and survive at nest sites for more than a few months.

\section{Methods and Results}

We monitored a hummingbird nest during incubation and brooding from 31 July through 18 August 2014 in a suburban yard in Fairfax County, VA (38 46.3'N, $77^{\circ} 5.7^{\prime} \mathrm{W}$; Graves 2014). The lichen-ornamented nest (Fig. 1) was built $\sim 9 \mathrm{~m}$ above

Figure 1. Incubating Archilochus colubris (Ruby-throated Hummingbird) photographed on $5 \mathrm{Au}-$ gust 2014. The nest is bound to the branch by spider or caterpillar silk. Lichen thalli are attached to the exterior of the nest including the underside of the supporting branch.

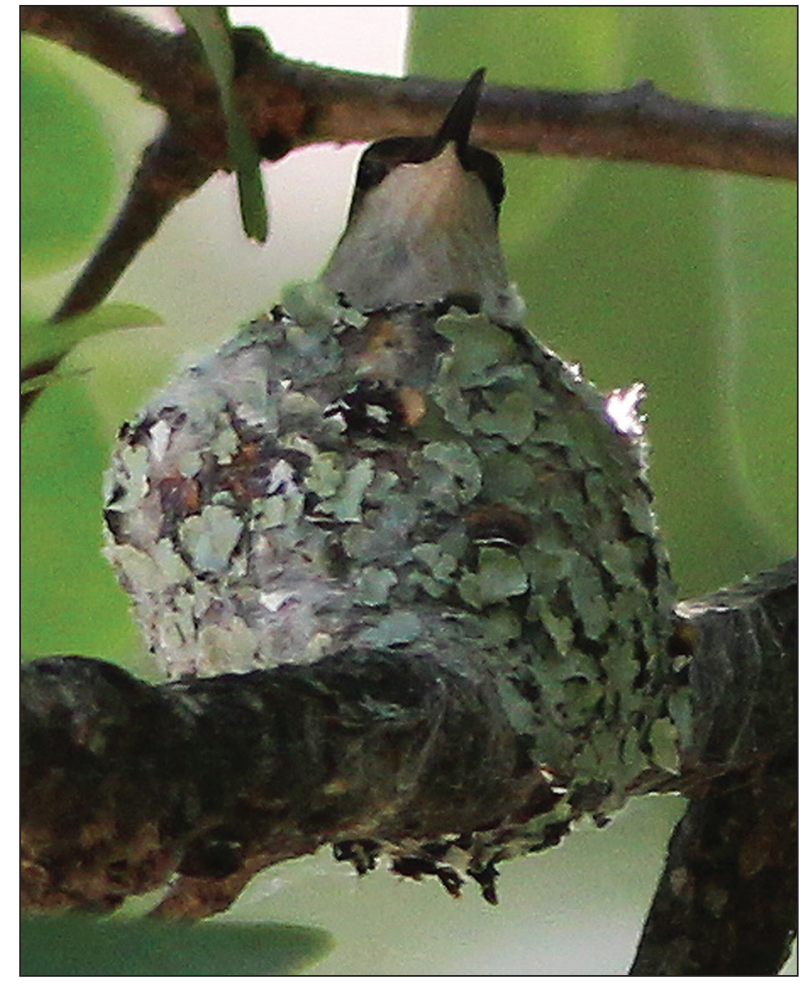


ground level on a thin, sloping branch in the subcanopy of a mature Quercus alba L. (White Oak). We observed the female hummingbird collecting flakes of lichen from the bark of an oak about $40 \mathrm{~m}$ from the nest site (Graves 2014) and spider silk from a nearby Lagerstroemia indica L. (Crapemyrtle). After the nestlings had fledged, we monitored the nest over the following winter to determine its fate. The slender supporting branch (13 mm diameter) died during the winter of 2014-2015. On 10 July 2015, we mounted the branch and nest remnant on a wooden support $3.5 \mathrm{~m}$ above ground where it would receive $4-6 \mathrm{~h}$ of direct sunlight each day. We used the hatching date (10 August 2014) as the zero day in calculating the persistence time of nest lichen.

We examined and photographed the nest on 28 December 2015 (506 d after hatching) [??]. It had eroded significantly and was reduced to compact pads of plant debris, bud scales, and lichen fragments bound by spider silk to the sides of the supporting branch (Fig. 2). Additional flakes of lichen were attached by silk to the

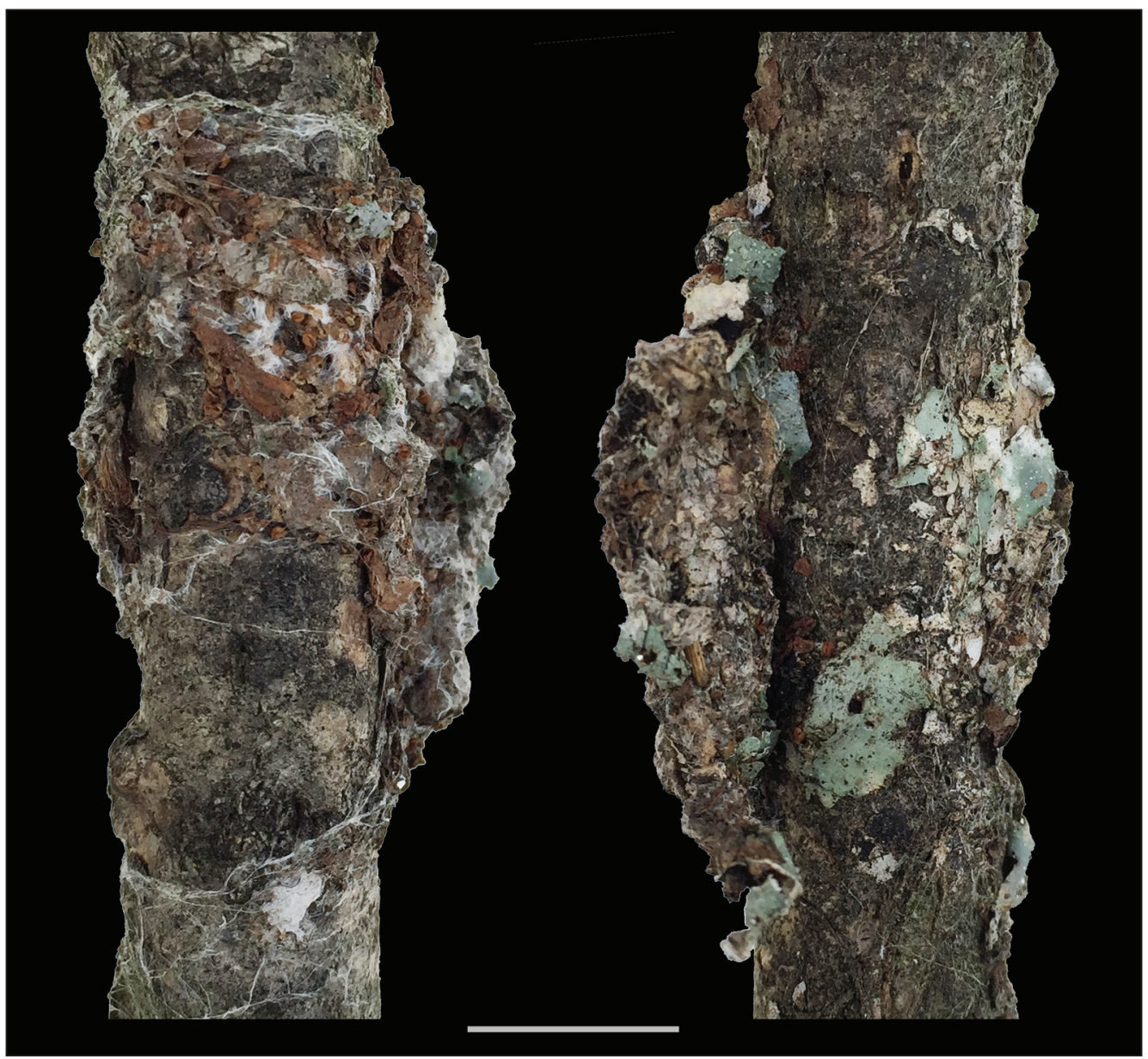

Figure 2. Decomposed nest on 28 December 2015 (506 d after hatching). Upper side of branch (left); lower side (right). Several lichen thalli are bound to the lower side of the branch with spider or caterpillar silk. Scale bar $=10 \mathrm{~mm}$. 
lower surface of the branch immediately below the base of the nest. We observed no other foliose lichen on the supporting branch or on thin branches of similar diameter on the nest tree.

Our observations terminated on 31 May 2017 (1026 d after hatching) when we discovered that a squirrel had knocked the branch off the supporting mount sometime during the previous month. We recovered the branch from the interior of a dense growth of garden flowers. Most of the lichen and binding silk that had been present on the nest substrate during the winter of 2016-2017 had disappeared. The remains of the largest lichen fragment visible in the righthand photograph in Fig. 2 were tenuously attached by 2 rhizines to the bark on the lower side of the branch, although we could not be certain whether the rhizines were bound by silk or had actually fastened to the bark. We subsampled this fragment for DNA extraction followed by fungal barcoding (Schoch et al. 2012).

The ITS region of nuclear DNA was Sanger-sequenced in the Laboratory for Analytical Biology (LAB) at the National Museum of Natural History (Washington, DC) following previously published protocols (Dal-Forno et al. 2013) and utilizing the primers ITS1F (Gardes and Bruns 1993) and ITS4 (White et al. 1990). A BLAST search of the contig of the 2 generated sequences in GenBank (http://blast. ncbi.nlm.nih.gov) revealed the sequence to be identical to that of Myelochroa aurulenta (GenBank \# JQ301701), which occurs widely on the bark of deciduous trees in eastern North America from North Carolina to New York (Brodo et al. 2001). Ours is the second record of $M$. aurulenta in the nest material of the Ruby-throated Hummingbird (see McCormac and Showman 2009-2010), and the first report confirmed by DNA barcoding. The 3 lichen taxa cited by McCormac and Showman (2009-2010) at the species level, i.e., P. sulcata, F. caperata, and M. aurulenta, are commonly observed species in northern Virginia.

\section{Discussion}

Abiotic factors appear to be the most important vehicles for dispersal of foliose lichens (Armstrong 1987, 1990; Goward 2003; Marshall 1996; Muñoz et al. 2004). Rain-splashing and running water facilitate short-distance dispersal, whereas wind enables the transport of soredia, isidia, and thallus fragments over longer distances. By comparison, the absolute volume of propagules transported by animals is likely negligible, although migratory birds are thought to be responsible for the amphitropical distributions of lichens north and south of the equator (Garrido-Benavent and Pérez-Ortega 2017).

In a broader context, our report and the records documented by McCormac and Showman (2009-2010) suggest that the Ruby-throated Hummingbird, with a global breeding population of $\sim 20$ million (Partners in Flight Science Committee 2013), may be a significant dispersal agent for foliose lichens at intermediate spatial scales $(10-100 \mathrm{~m})$ in eastern North America. Whereas the vast majority of wind-blown lichen fragments in forested landscapes may fall on substrates that are unsuitable for colonization (e.g., shaded leaf litter), thalli transported by hummingbirds are placed in favorable orientations with the pale upper surfaces facing outward on 
compact substrates at well-lit, elevated nest sites. This observation yields a testable hypothesis - lichen species frequently used as nest material by Ruby-throated Hummingbird, and other species that habitually adorn their nests with lichen (e.g., Polioptila caerulea (L.) [Blue-gray Gnatcatcher]) may have relatively large geographic ranges and an enhanced ability to colonize fragmented habitats.

Finally, investigators should determine whether transported thalli retain viability at nest sites. In the case we report here, thallus fragments persisted for nearly 3 years, but we observed no growth or reproduction, so we could not be certain if they were still viable. Long-term monitoring (3-5 y) of hummingbird-nest sites and transplantation experiments (Smith 2014) using thalli salvaged from decomposing nests would shed considerable light on the role of hummingbirds as dispersal agents.

\section{Acknowledgments}

We thank David Richardson and an anonymous reviewer for comments on the manuscript. G.R. Graves thanks the Smoketree Trust for support and M. Dal-Forno thanks the National Science Foundation for a Postdoctoral Research Fellowship in Biology (PRFB 1609022).

\section{Literature Cited}

Armstrong, R.A. 1987. Dispersal in a population of the lichen Hypogymnia physodes. Environmental and Experimental Botany 27:357-363.

Armstrong, R.A. 1990. Dispersal, establishment, and survival of soredia and fragments of the lichen, Hypogymnia physodes (L.) Nyl. New Phytologist 114:239-245.

Audubon, J.J. 1835. Ornithological Biography, Vol. 3. Adam and Charles Black, Edinburgh, UK. 638 pp.

Bailey, R.H. and P.W. James. 1979. Birds and the dispersal of lichen propagules. Lichenologist 11:105-106.

Bent, A.C. 1940. Life histories of North American cuckoos, goatsuckers, hummingbirds, and their allies. Bulletin of the United States National Museum 176:1-506.

Brodo, I.M., S.D. Sharnoff, and S. Sharnoff. 2001. Lichens of North America. Yale University Press, New Haven, CT. 828 pp.

Collias, N.E. and E.C. Collias. 1984. Nest Building and Bird Behavior. Princeton University Press, Princeton, NJ. 358 pp.

Dal-Forno, M., J.D. Lawrey, M. Sikaroodi, S. Bhattarai, P.M. Gillevet, M. Sulzbacher, and R. Lucking. 2013. Starting from scratch: Evolution of the lichen thallus in the basidiolichen Dictyonema (Agaricales: Hygrophoraceae). Fungal Biology 117:584-598.

Gardes, M., and T.D. Bruns. 1993. ITS primers with enhanced specificity for basidiomycetes-applicaton to the identification of mycorrhizae and rusts. Molecular Ecology 2:113-118.

Garrido-Benavent, I., and S. Pérez-Ortega. 2017. Past, present, and future research in bipolar lichen-forming fungi and their photobionts. American Journal of Botany 104:1660-1674.

Goward, T. 2003. On the dispersal of hair lichens (Bryoria) in high-elevation, old-growth conifer forests. Canadian Field-Naturalist 117:44-48.

Graves, G.R. 2014. Compass orientation of an incubating and brooding Ruby-throated Hummingbird (Archilochus colubris). Banisteria 44:21-23. 
Hansell, M.H. 1996. The function of lichen flakes and white spider cocoons on the outer surface of birds' nests. Journal of Natural History 30:303-311.

Hansell, M. 2000. Bird Nests and Construction Behaviour. Cambridge University Press, Cambridge, UK. 296 pp.

Lewis, L.R., E. Behling, H. Gousse, E. Qian, C.S. Elphick, J.-F. Lamarre, J. Bety, J. Liebezeit, R. Rozzi, and B. Goffinet. 2014. First evidence of bryophyte diaspores in the plumage of transequatorial migrant birds. PeerJ 2:e424. DOI:10.7717/peerj.424.

Marshall, W.A. 1996. Aerial dispersal of lichen soredia in the maritime Antarctic. New Phytologist 134:523-530.

McCormac, J. and R.E. Showman. 2009-2010. Lichen composition in Blue-gray Gnatcatcher and Ruby-throated Hummingbird nests. Ohio Cardinal 33:72-82.

Muñoz, J., Á.M. Felicísimo, F. Cabezas, A.R. Burgaz, and I. Martínez. 2004. Wind as a long-distance dispersal vehicle in the Southern Hemisphere. Science 304:1144-1147.

Partners in Flight Science Committee. 2013. Population estimates database, version 2013. Available online at http://rmbo.org/pifpopestimates/Database.aspx. Accessed on 7 July 2014).

Richardson, D.H.S. 1974. The Vanishing Lichens. David and Charles, London, UK. 231 pp.

Richardson, D.H.S., and C.M. Young. 1977. Lichen and vertebrates. Pp. 121-144, In M.R.D. Seaward (Ed.). Lichen Ecology. Academic Press, London, UK. 550 pp.

Saunders, A.A. 1929. The summer birds of the northern Adirondack Mountains. Roosevelt Wild Life Bulletin 5:327-499.

Schoch, C.L., K.A. Seifert, S. Huhndorf, V. Robert, and J.L. Spouge. 2012. Nuclear ribosomal internal transcribed spacer (ITS) region as a universal DNA barcode marker for fungi. Proceedings of the National Academy of Sciences of the United States of America 109:6241-6246.

Schuchmann, K.-L. 1999. Family Trochilidae. Pp. 468-680, In J. del Hoyo, A. Elliott, and J. Sargatal (Eds.). Handbook of the Birds of the World. Volume 5: Barn-owls to Hummingbirds. Lynx Edicions, Barcelona, Spain. 759 pp.

Smith, P.L. 2014. Lichen translocation with reference to species conservation and habitat restoration. Symbiosis 62:17-28.

Tyler, W.M. 1940. Archilochus colubris (Linnaeus) Ruby-throated Hummingbird. Pp. 332-352, In A.C. Bent (Ed.). Life Histories of North American Cuckoos, Goatsuckers, Hummingbirds, and Their Allies: Orders Psittaciformes, Cuculiformes, Trogoniformes, Coraciiformes, Caprimulgiformes and Micropodiiformes. US Government Printing Office, Washington, DC. 506 pp.

Weidensaul, S., T.R. Robinson, R.R. Sargent, and M.B. Sargent. 2013. Ruby-throated Hummingbird (Archilochus colubris). No. 204, In A. Poole (Ed.). The Birds of North America Online. Cornell Lab of Ornithology, Ithaca, NY. Available online at http://bna. birds.cornell.edu.bnaproxy.birds.cornell.edu/bna/species/204. Accessed 6 August 2014.

White, T.J., T. Bruns, S. Lee, and J.W. Taylor. 1990. Amplification and direct sequencing of fungal ribosomal RNA genes for phylogenetics. Pp. 315-322, In M.A. Innis, D.H. Gelfand, J.J. Sninsky, and T.J. White (Eds.). PCR Protocols: A Guide to Methods and Applications. Academic Press, New York, NY. 482 pp.

Wilson, A. 1828. American Ornithology, Volume 2. Pp 77-78. Collins and Company, New York, NY. 456 pp. 